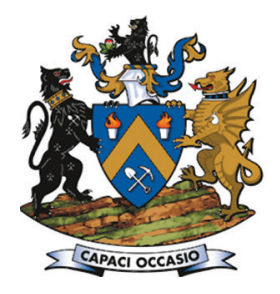

Affiliation:

'School of Chemical and

Metallurgical Engineering,

University of the Witwatersrand,

South Africa

2Scaw Metals Group,

South Africa

Correspondence to:

E. Matinde

Email:

elias.matinde@wits.ac.za

Dates:

Received: 5 Sep. 2018

Revised: 15 Mar. 2018

Accepted: 1 Apr. 2019

Published: June 2019

How to cite:

Matinde, E. and Msibi, S.L.

Effect of reclaimed bauxite on

andalusite-based refractory

castables for tundish applications.

The Southern African Insitute of

Mining and Metallurgy

DOI ID:

http://dx.doi.org/10.17159/2411-

9717/311/2019

ORCiD ID:

E. Matinde

https://orchid.org/0000-0001-

7899-3311

\section{Effect of reclaimed bauxite on andalusite-based refractory castables for tundish applications}

\author{
E. Matinde ${ }^{1}$, and S.L. Msibi ${ }^{1,2}$
}

\begin{abstract}
Synopsis
The robust nature of alumina refractory materials presents opportunities for their in-process reclaiming and re-use in non-critical applications. Virgin refractories can be substituted with different quantities of reclaimed materials without compromising the quality of the refractory products. In this study, the effect of reclaimed bauxite on andalusite-containing refractory castables for tundish applications was investigated. The recycled bauxite was formulated in different proportions to replace virgin andalusite in the castables. Standard tests were conducted to evaluate the physical, physicochemical, and thermochemical properties of the formulated products. Static corrosion tests were conducted using tundish slag in order to simulate the actual operating conditions. The results show that the standard flow behaviour, open porosity, and bulk density of samples containing up to 22 mass $\%$ reclaimed bauxite were comparable to those of the reference castable. However, high-temperature properties such as static corrosion at $1400^{\circ} \mathrm{C}$ and hot modulus of rupture at $1500^{\circ} \mathrm{C}$ indicated that there is an upper constraint to the amount of substitution. The study demonstrated direct potential savings of up to $10 \%$ when the reclaimed alumina replacement ratio was increased to 22 mass\%.
\end{abstract}

\section{Keywords}

andalusite, bauxite, recycling and re-use, refractory castables, apparent porosity, bulk density, static corrosion test.

\section{Introduction}

Alumina-based refractories can be classified into low-alumina, containing less than $50 \% \mathrm{Al}_{2} \mathrm{O}_{3}$, and high-alumina or bauxite, containing between 50 and $90 \% \mathrm{Al}_{2} \mathrm{O}_{3}$. High-alumina refractories have widespread applications in high-temperature metal extraction processes due to their outstanding thermochemical and thermomechanical properties and stability (Rebouillat and Rigaud, 2002; Frulli, 2016). The typical chemical composition of refractory-grade bauxite consists of $85-90 \mathrm{wt} . \% \mathrm{Al}_{2} \mathrm{O}_{3}$, 5-10 wt.\% $\mathrm{SiO}_{2}, 1-2 \mathrm{wt} . \% \mathrm{Fe}_{2} \mathrm{O}_{3}, 3-4$ wt.\% $\mathrm{TiO}_{2}, 0.4-0.8$ wt.\% $\mathrm{CaO}+\mathrm{MgO}$, and 0.20-0.8 wt.\% $\mathrm{K}_{2} \mathrm{O}+$ $\mathrm{Na}_{2} \mathrm{O}$ (Nyoka et al., 2013). The thermochemical and thermomechanical properties of bauxite-based refractories rely principally on the conversion of the contained silica and alumina to the highly stable corundum $\left(\alpha-\mathrm{Al}_{2} \mathrm{O}_{3}\right)$ and mullite $\left(3 \mathrm{Al}_{2} \mathrm{O}_{3} \cdot 2 \mathrm{SiO}_{2}\right)$ phases (Rebouillat and Rigaud, 2002; Hill and Sehnke, 2006; Garbers-Craig, 2008; Frulli, 2016).

Due to the high costs and supply-chain constraints of bauxite, the high-alumina refractories are increasingly being replaced by the cheaper and more readily available andalusite (Rebouillat and Rigaud, 2002; Hill and Sehnke, 2006; Garbers-Craig, 2008; Nyoka et al., 2013; Frulli, 2016). Andalusite is an industrial mineral containing about $57-59.5$ wt. $\% \mathrm{Al}_{2} \mathrm{O}_{3}, 38-40 \mathrm{wt}$.\% $\mathrm{SiO}_{2}, 0.6-0.8$ wt.\% $\mathrm{Fe}_{2} \mathrm{O}_{3}, 0.15-0.25$ wt.\% $\mathrm{TiO}_{2}, 0.1-0.25$ wt.\% $\mathrm{CaO}, 0.1-0.15$ wt.\% MgO, 0.1 wt.\% $\mathrm{Na}_{2} \mathrm{O}$, and 0.2$0.35 \mathrm{wt} . \% \mathrm{~K}_{2} \mathrm{O}$ (Nyoka et al., 2013). Andalusite forms part of the trimorphous group with stoichiometry $\mathrm{Al}_{2} \mathrm{SiO}_{5}$. This group also contains sillimanite and kyanite. These minerals yield a mixture of silica $\left(\mathrm{SiO}_{2}\right)$ glass phase and mullite $\left(3 \mathrm{Al}_{2} \mathrm{O}_{3} \cdot 2 \mathrm{SiO}_{2}\right.$ or $\left.\mathrm{Al}_{2} \mathrm{O}_{3} \cdot \mathrm{SiO}_{2}\right)$ when heated in air in the temperatures range $1100-1480^{\circ} \mathrm{C}$ (Equation [1]) (Rebouillat and Rigaud, 2002; Garbers-Craig, 2008; Abou-Sekkina et al., 2011; Frulli, 2016).

$$
3 \mathrm{Al}_{2} \mathrm{O}_{3} \cdot \mathrm{SiO}_{2} \text { (andalusite) } \longrightarrow 3 \mathrm{Al}_{2} \mathrm{O}_{3} \cdot 2 \mathrm{SiO}_{2} \text { (mullite) }+\mathrm{SiO}_{2} \text { (glass) }
$$

The mullite phases are thermodynamically stable at high temperatures, and possess good refractory properties such as low thermal expansion, low thermal conductivity, good chemical stability, and excellent thermomechanical stability (Abou-Sekkina et al., 2011; Frulli, 2016). Since andalusite transforms to mullite at relatively low temperatures with minor volume expansion, it has widely been used in both fired bricks and in unfired (unfired bricks, castables, plastic mixes) refractory materials for various applications (Rebouillat and Rigaud, 2002; Frulli, 2016). 


\section{Effect of reclaimed bauxite on andalusite-based refractory castables for tundish applications}

\section{Recycling of alumina-based refractory materials}

When the degree of in-service damage to alumina-based refractories is such that stable operation of high-temperature processes cannot be ensured, the materials are broken down and discarded (Hanagiri et al., 2008). However, the non-destructible nature of these refractories poses environmental challenges in the form of disposal space and particulate dust emissions. Nonetheless, the robust nature of alumina-based refractories presents opportunities as well, particularly for their in-process recyclability and re-use, as well as their re-use in other industry sectors (Ndlovu, Simate, and Matinde, 2017). In recent years there has been an increasing demand to recycle the spent refractories by incorporating them into a variety of refractory finished products (Bradley and Hutton 2014; Ndlovu, Simate, and Matinde, 2017). In fact, spent alumina-based refractories can easily be re-used in the production of conventional monolithic refractory products, and have long been regarded as fit-forpurpose grades in the substitution of virgin refractory raw materials (Hanagiri et al., 2008; Bradley and Hutton, 2014).

To date, the in-process recycling of reclaimed refractory materials has focused on developing refractory products for low-temperature and non-critical applications (Mazzanti et al., 2010; Schutte, 2010; Bradley and Hutton, 2014). Schutte (2010) investigated the potential for recycling of spent chamotte (calcined aluminosilicate clay), andalusite, and magnesia spinel refractory materials for use as monolithic materials, and proposed that new product formulations containing up to 70-80 wt.\% reclaimed material can be used in non-critical and lowtemperature applications. Mazzanti et al. (2010) proposed that spent alumina refractory materials can be reclaimed and used in producing medium to high alumina-based castables with little or no compromise on the product quality. Based on the principle of downward position, Hanagiri et al. (2008) developed a methodology to recycle processed refractory waste wherein the reprocessed materials are used to produce materials of lower quality than the original materials. In other studies, Kumar et al. (2014) developed a new class of conventional and lowcement castables using $40 \mathrm{wt}$ \% ferrochrome slag and $45 \mathrm{wt} . \%$ calcined alumina. The findings from these studies have proved the suitability of the products made from the recycled materials. Based on the findings from these studies, the broad objective of this study is to investigate the potential utilization of reclaimed alumina refractories in the production of refractory castables for non-critical applications.

The recycling of spent refractories for castable applications requires optimization of interrelated properties such as particle size distribution (PSD), porosity, and thermochemical and thermomechanical properties, and hence a fundamental knowledge of their thermophysical, thermochemical (corrosion/ erosion resistance), and thermomechanical behaviour (thermal, volume, and mechanical stability). Their degradation behaviour when contacted with process materials such as molten oxides, molten metals, and corrosive and abrasive gases commonly found in most high-temperature metal extraction processes is particularly important from a safety perspective (Kumar et al., 2015; Sadik, El-Amraniand, and Albizane, 2014). Standard tests are often conducted in order to determine the physical, physicochemical, thermomechanical, and thermochemical behaviour of these materials under simulated conditions of service. Since refractory castables consist of matrix and aggregate phases, the optimization of the PSD of the starting materials is one of the key requirements in the formulation of refractory castables. According to Fruhstorfer and Aneziris (2014), the central problem in designing unshaped refractory castables involves the simultaneous optimization of the interrelated properties of stability, flowability, and density. In particular, the PSDs, especially those of the coarse aggregates, play a critical role in obtaining the desired final properties, due to their effect on the final particle-packing density. The particle density packing, in turn, has a significant effect on physical properties such as apparent porosity and bulk density (Schutte, 2010; Fruhstorfer and Aneziris, 2014). Fruhstorfer and Aneziris (2014) proposed that the PSD of coarse refractories consists of fine particle fractions $(<0.1 \mathrm{~mm})$, medium grain sizes (between 0.1 and 1 $\mathrm{mm})$, and coarse grains (>1 mm). Schutte (2010) also proposed that the coarse aggregate fractions (1-3 mm and 3-5 mm) are usually considered for substitution during the recycling process. The matrix components, which include calcium aluminate cement binder, fillers, and deflocculating additives, are often not changed to reduce the effect of recycled materials on the flowability, workability, early strength, and volume stability of the formulated castable (Schnabel et al., 2014).

As highlighted earlier, the thermochemical and thermomechanical properties of refractory castables are critical from a safety perspective. Properties such as the hot modulus of rupture (HMOR) and corrosion/erosion resistance are some of the most important characteristics of refractory castables that determine their applicability in various processes. The HMOR is determined by a three-point bending test and is indicative of the strength of the bond in the refractory at high temperatures, and is thus correlated to resistance to structural degradation, chemical slag attack, and abrasion wear (Hancock and Cannon, 2000; ASTM C583; Kumar, Kumar-Singh, and Strivastava, 2013). In contrast, the corrosion of refractory castable involves phenomena of chemical dissolution of refractory phases as well as the precipitation of new crystalline phases, while abrasion wear involves mechanical wear by high-velocity gases or flowing liquid phases. In other words, refractories must not only resist high temperatures but must also resist both corrosion and abrasion attack by liquid oxides and process gases (Kumar et al., 2015; Sadik, El-Amraniand, and Albizane, 2014).

This study investigated the recycling of spent high-alumina refractories reclaimed from an electric arc furnace (EAF) roof at a ferrous foundry in Johannesburg, South Africa. The initial working lining thickness of the roof bricks is usually $270 \mathrm{~mm}$, and the residual thickness at the end of each campaign is around $135 \mathrm{~mm}$ or more. This translates to $50 \%$ or more of the original thickness being unused before the furnace roof is demolished (see Figure 1). In some cases, the remaining thickness of the bricks can be as high as $80 \%$ of the original. This implies that a significant portion of the brick remains unused but is still discarded, thereby presenting opportunities for sufficient quantities to be recycled.

The foundry consumes over $2500 \mathrm{t}$ of fresh alumina refractory materials per year. A $10 \mathrm{t}$ tundish is used in the final steel-refining operation. Currently, the tundish lining consists of a $200 \mathrm{~mm}$ permanent/safety lining based on virgin andalusite and a $50 \mathrm{~mm} \mathrm{MgO} \cdot \mathrm{SiO}_{2}$-based working lining. To date, no initiatives have been undertaken to recycle the spent refractory products. In this study, the effect of reclaimed bauxite addition on andalusitebased safety lining was investigated (see Figure 2). The working lining is replenished by gunning after casting several 


\section{Effect of reclaimed bauxite on andalusite-based refractory castables for tundish applications}

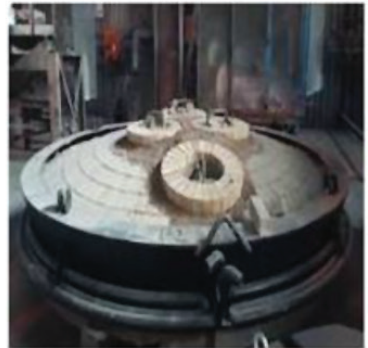

(a): Condition of the roof bricks before campaign

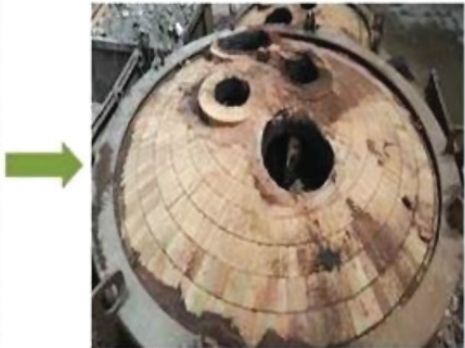

(b) Condition of the roof bricks after campaign

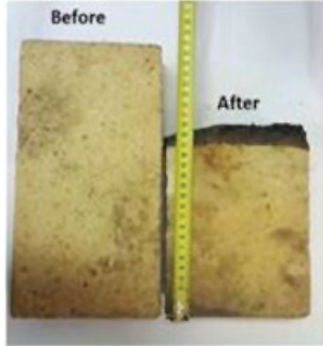

(c) Residual thickness of individual bricks after campaign

Figure 1-Condition of the furnace roof (a) before and (b) after service, and (c) the average residual thickness of individual bricks (photographs by S.L. Msibi, taken on 5 December 2016)

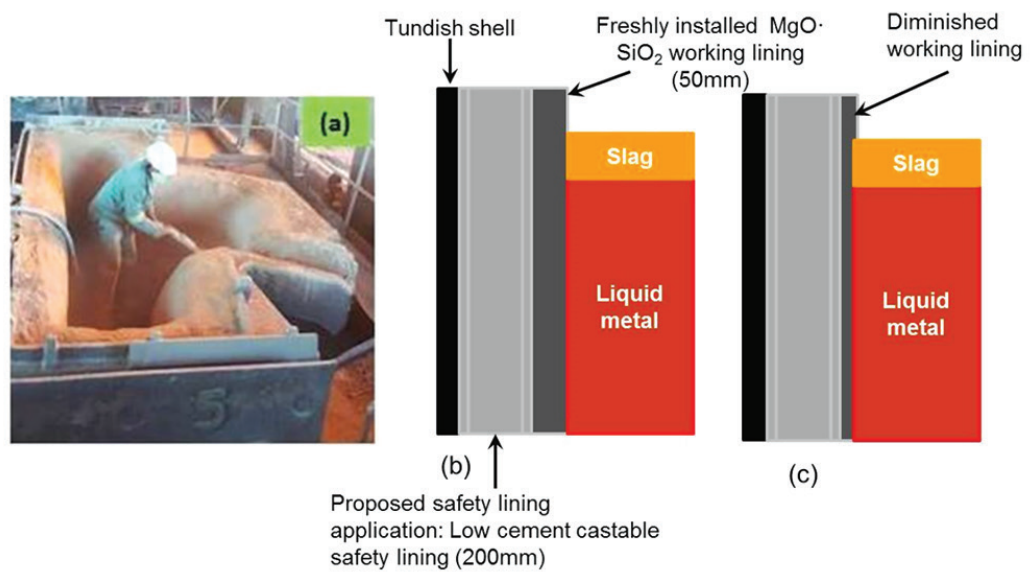

Figure 2-Depiction of (a) freshly lined tundish, and the simulated tundish lining configuration with the (b) new and (c) diminished working lining

ladles (Figure 2). In this case, the tundish permanent lining is considered to be a semi-critical application, as the temperatures in the tundish hardly exceed $1565^{\circ} \mathrm{C}$ even when the thickness of the $\mathrm{MgO} \cdot \mathrm{SiO}_{2}$ hot face or working lining diminishes due to slagmetal attack.

Figures $2 \mathrm{a}$ and $2 \mathrm{~b}$ illustrate the freshly lined tundish castable and the configuration of the new working lining before slag-metal attack, respectively. Figure 2c shows the schematic representation of the diminished working lining after slag-metal attack. As shown in Figure 2, the proposed application of the formulated safety lining castable does not involve direct contact with the metal or slag unless the working lining is penetrated or diminishes completely. Nevertheless, the safety lining castable should be robust enough to resist penetration by liquid slag and steel in order to prevent breakouts should the working lining diminish to a critical thickness.

\section{Experimental procedure}

Three sets of tests were conducted. The first set of tests was conducted to evaluate the recyclability of the furnace bricks. The second set focused on the formulation of castables based on the specifications of the as-received reference castable. The final tests focused on the physicochemical and thermochemical properties of the castables. The following sections describe the characterization and standard tests that were conducted in order to simulate the physical, chemical, and thermal properties, and the performance of the formulated product under simulated service conditions in the tundish.

\section{Selection of reclaimed roof bricks for recycling}

In order to determine the recyclability, brick samples were randomly selected from the EAF roof at different locations, as shown in Figure 3. Brick (a) was reclaimed from the periphery of the roof. Brick (b) was reclaimed from the electrode pot area, while brick (c) was reclaimed from the off-gas chute. It is clear that the wear profiles of these bricks were not uniform across the entire furnace roof. The selected brick samples were then characterized using scanning electron microscopy (SEM) and $\mathrm{X}$-ray diffraction (XRD) techniques in order to determine the phase compositions.

\section{Formulation of castables containing reclaimed alumina}

The castables were formulated based on different proportions of reclaimed alumina (referred to here as grog) to virgin castable. Castable mixtures of $15 \mathrm{~kg}$ per sample were prepared from the crushed reclaimed bricks and virgin andalusite (see Table I). Only the $<1 \mathrm{~mm}, 1-3 \mathrm{~mm}$, and 3-6 mm aggregates of the castable were considered for substitution. As shown in Figure 4, the particle size distribution of the fractions considered for substitution was comparable to that of the virgin gunning material provided by the refractory supplier.

Since the rheological and thixotropic behaviour of refractory castables is primarily influenced by amount of sub-micrometre 


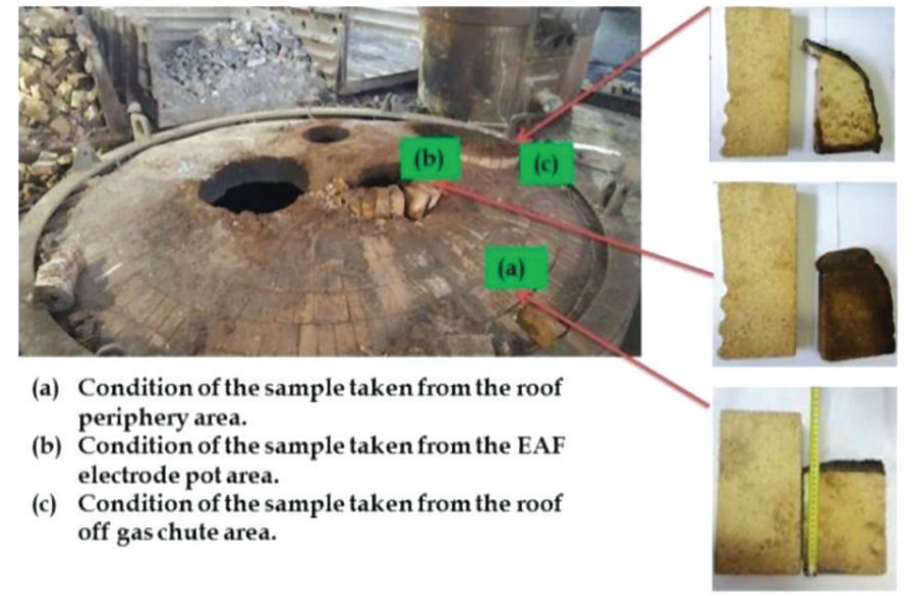

Figure 3-Selection and visual conditions of the reclaimed refractory bricks after campaign

Table I

Mixing ratios of formulation of castables (mass \%)

\begin{tabular}{|c|c|c|c|c|c|}
\hline Description & Virgin sample (VS) & 8 mass $\%$ grog (S1) & 14 mass $\%$ grog (S2) & 22 mass $\%$ grog (S3) & 28 mass $\%$ grog (S4) \\
\hline Binder premix & 8 & 8 & 8 & 8 & 8 \\
\hline Calcined alumina & 2 & 2 & 2 & 2 & 2 \\
\hline Bauxite grog 0-1 mm & 0 & 2 & 4 & 6 & 8 \\
\hline Bauxite grog 1-3 mm & 0 & 4 & 7 & 11 & 14 \\
\hline Bauxite grog 3-6 mm & 0 & 2 & 3 & 5 & 6 \\
\hline Andalusite $200 \mu \mathrm{m}$ & 20 & 20 & 20 & 20 & 20 \\
\hline Andalusite $<1 \mathrm{~mm}$ & 20 & 18 & 16 & 14 & 12 \\
\hline Andalusite $1-3 \mathrm{~mm}$ & 35 & 30 & 28 & 24 & 21 \\
\hline Andalusite $3-6 \mathrm{~mm}$ & 15 & 14 & 12 & 10 & 9 \\
\hline Total (\%) & 100 & 100 & 100 & 100 & 100 \\
\hline
\end{tabular}

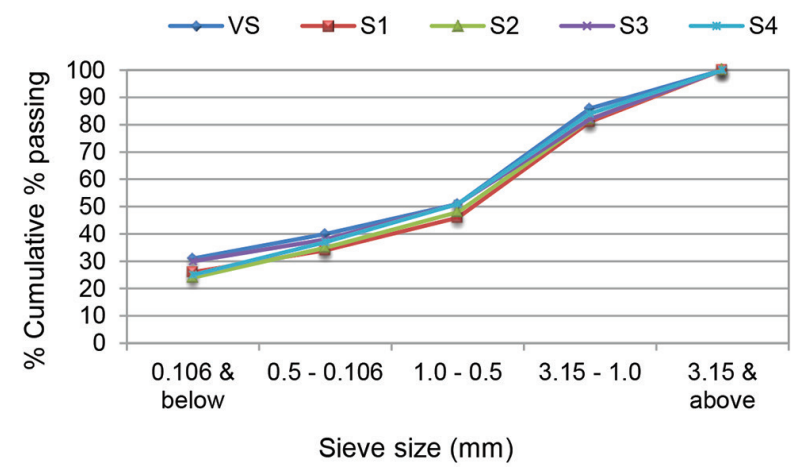

Figure 4-Particle size distribution of the as-received andalusite and formulations

particles and binders, a binding premix, consisting of calcium alumina cement (CAC), admixture, and microsilica was maintained at 8 mass $\%$ of the total formulation. The calcined alumina content also remained unchanged at 2 mass $\%$ based on the specifications of the reference castable from the refractory supplier. Furthermore, the $200 \mu \mathrm{m}$ size fraction for andalusite was also fixed at 20 mass\% of the formulation. No other additives, in the form of accelerator or retarders were added to modify the placing properties of the refractory castable. The current formulation was guided by the need to replicate the reference formulation, which does not contain additives. The chemical composition of the formulated products was analysed by X-ray fluorescence (XRF) and the crystalline phases were analysed using XRD. These properties were then compared to those of the virgin andalusite sample.

\section{Standard tests on formulated castables}

\section{Castable flow behaviour and water addition}

The amount of water added was controlled to achieve the desired flow behaviour and workability based on the specifications of the reference castable. The flow behaviour was measured using the ASTM C1446 method, wherein a cone $(100 \mathrm{~mm}$ base, $50 \mathrm{~mm}$ height, and $70 \mathrm{~mm}$ top diameter) was filled with the castable and vibrated for 30 seconds. The percentage self-flow (\% S.F.) of the castable was calculated from the ratio of final $\left(D_{f}\right)$ to the initial $\left(D_{i}\right)$ diameter using the formula (ASTM 1446, 2011; Myhre, Sandberg, and Hundere, 1998):

$$
\% \text { S.F. }=\frac{100 \times\left(D_{f}-D_{i}\right)}{D_{i}}
$$

\section{Bulk density and apparent porosity}

The bulk density and apparent porosity of formulated castables ( $50 \times 50$ x $50 \mathrm{~mm}$, fired at $110,600,1000$, and $1200^{\circ} \mathrm{C}$ for 24 hours) were measured based on Archimedean evaluation method (ASTM C20-00; Harbison and Walker, 2005). The bulk density and apparent porosity values were calculated as: 


\section{Effect of reclaimed bauxite on andalusite-based refractory castables for tundish applications}

$$
\begin{aligned}
& \text { Bulk density (B.D): } \frac{\text { Mass in air }}{\sqrt{\text { Soaked mass-Suspended mass }}} \times \text { liquid density } \\
& \text { Apparent porosity: } \frac{\text { Soaked mass-Mass in air }}{\text { Soaked mass-Suspended mass }} \times 100
\end{aligned}
$$

\section{Static corrosion test}

The static corrosion tests were conducted in accordance with the DIN 51069 Blatt 2 test at $1400^{\circ} \mathrm{C}$ for 12 hours in order to determine the potential for isothermal chemical interaction between tundish slag and formulated castables (DIN Blatt 2, 1972). The samples were moulded into cubes with a cylindrical section core- drilled to specified dimensions of $50 \mathrm{~mm}$ diameter and $35 \mathrm{~mm}$ depth. The cylindrical holes were then filled with an equal amount of slag and covered with a lid of the same refractory material. The refractory specimen was heated to $1400^{\circ} \mathrm{C}$ in a carbolite furnace (heating rate $5-8^{\circ} \mathrm{C} / \mathrm{min}$ ) and soaked at that temperature for 12 hours to allow for sufficient refractory-slag interaction. After firing, the samples were left to cool inside the furnace for 24 hours, and were then sectioned to evaluate the corrosion pattern of each brick using SEM analysis. Based on the initial dimensions (50 $\mathrm{mm} \Phi$ and $35 \mathrm{~mm}$ depth), the corresponding volume change after reaction was calculated by measuring the change in the diameter and depth due to slag penetration. The volume change, estimated as percentage corrosion volume, was calculated according to Equation [5].

$$
\% \text { Corrosion Volume }=\left(\frac{V_{f}-V_{i}}{V_{i}}\right) \times 100
$$

where $V_{i}$ is the initial volume and $V_{f}$ is the final volume.

\section{Hot modulus of rupture}

HMOR tests were conducted at temperatures close to the actual operating temperatures in the tundish. Bar samples $(25 \times 25$ $\times 150 \mathrm{~mm}$ ) were heated to $1500^{\circ} \mathrm{C}$ at a rate of $5-8^{\circ} \mathrm{C} / \mathrm{min}$. The samples were soaked at this temperature, and then a three-point bending test was conducted until failure. The procedure was repeated six times. The HMOR values were calculated as:

$$
\operatorname{HMOR}(\mathrm{MPa})=\frac{3 P L}{2 d b^{2}}
$$

where $P$ is the maximum force applied at rupture $(\mathrm{N}), L$ is the span between the supports (mm), $b$ is the width of the specimen $(\mathrm{mm})$, and $d$ is the depth of the specimen.

\section{Results and discussion}

\section{Characterization of raw materials and reclaimed bricks}

Table II shows the composition of the as-received (unfired) andalusite and the reclaimed bauxite. Figures 5-7 show photographs, backscattered electron images, and the unnormalized chemical compositions of the three bricks. The three brick zones are labelled as: (1) the contaminated area (referred to as A 1-slag), (2) the interface (A 2 interface), and (3) the unreacted portion (A 3-brick). The compositional analyses of the respective portions also showed minimal slag/refractory brick interaction.

\section{Characterization of brick (a)}

Figure 5 shows the characterisation of the brick excavated from the periphery of the roof. The preliminary visual inspection showed that brick (a) was intact, with minimum signs of thermal and chemical degradation.

The A 1-slag zone consists predominantly of $\mathrm{FeO}, \mathrm{SiO}_{2}$ and $\mathrm{Al}_{2} \mathrm{O}_{3}, \mathrm{MgO}, \mathrm{CaO}, \mathrm{Na}_{2} \mathrm{O}$, and $\mathrm{K}_{2} \mathrm{O}$, with a calculated basicity $\left(\mathrm{CaO}+\mathrm{MgO} / \mathrm{SiO}_{2}+\mathrm{Al}_{2} \mathrm{O}_{3}\right)$ of 0.34 . The oxide phases can be attributed to result from the direct fly-off of process materials during introduction of powder materials into the EAF and/or the projection of liquid droplets from the bath at the impact points of the arc and/or of the oxygen jets on the steel bath (Guézennec et al., 2005; Brosnan, 2004). The presence of FeO tends to reduce the liquidus temperatures of the corrosion reaction products (Brosnan, 2004), and hence is likely to promote the early formation of liquid phases and an increased wear rate of the hot face of the brick (Lee and Zhang, 2004).

\section{Table II}

\section{Composition of as-received (unfired) andalusite and reclaimed bauxite (mass $\%$ )}

\begin{tabular}{|l|c|c|c|c|c|c|}
\hline & $\mathbf{A l}_{2} \mathbf{O}_{3}$ & $\mathbf{S i O}_{2}$ & $\mathbf{F e}_{2} \mathbf{O}_{3}$ & $\mathbf{T i O}_{2}$ & $\mathbf{M g O}+\mathbf{C a O}$ & $\mathbf{K}_{2} \mathbf{O}+\mathbf{N}_{2} \mathbf{O}_{3}$ \\
\hline Andalusite & 59.40 & 39.00 & 0.85 & 0.15 & 0.20 & 0.40 \\
Recycled bauxite brick & 81.80 & 12.60 & 1.60 & 3.20 & 0.30 & 0.50 \\
\hline
\end{tabular}

Brick (a)-Periphery

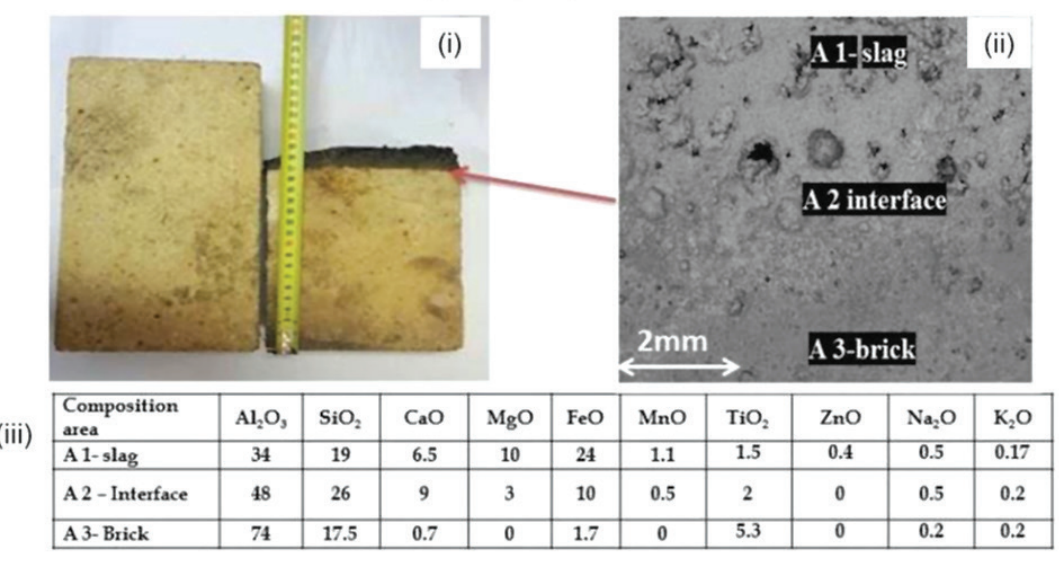

Figure 5-Characterization of brick (a) showing (i) the pictorial representation of the brick, (ii) the backscattered electron image, and (iii) un-normalized EDS compositional (mass\%) analysis 


\section{Effect of reclaimed bauxite on andalusite-based refractory castables for tundish applications}

Alkali compounds $\left(\mathrm{Na}_{2} \mathrm{O}\right.$ and $\left.\mathrm{K}_{2} \mathrm{O}\right)$ are typical volatile compounds present in the electric arc furnace dust (de Buzin, Heck and Vilela. 2017; Sofilić et al., 2004; Prigent, Bouchetou, and Poirier, 2011). Similar to FeO, these materials also lower the liquidus temperatures of the deposited materials, and would thus contribute to accelerated wear of refractory bricks (Prigent, Bouchetou, and Poirier, 2011). Prigent, Bouchetou, and Poirier (2011) investigated the corrosion of alumina raww materials by sodium vapours. Their findings indicate corrosion phenomena characterized by a dissolution-precipitation process caused by $\mathrm{Na}_{2} \mathrm{O}$-rich liquid phases. However, due to the low contents of $\mathrm{Na}_{2} \mathrm{O}$ and $\mathrm{K}_{2} \mathrm{O}$ in the materials deposited on the brick surface, the effect of these compounds on the liquidus temperature could not be quantified in the present study. The presence of $\mathrm{TiO}_{2}$ as an impurity in bauxite bricks (see Table II) is also detrimental to the integrity of the brick. $\mathrm{TiO}_{2}$ compounds tend to react with $\mathrm{SiO}_{2}$ to form low-melting glass phases when the bricks are fired and/or exposed to high temperatures in service (Hancock and Cannon, 2000; Harbison and Walker 2000).

\section{Characterization of brick (b)}

The brick reclaimed from the electrode area exhibited signs of severe thermal and chemical degradation (see Figure 6). Refractory materials close to the electrodes tend to experience severe degradation due to the high temperatures from the arc and aggressive chemical and abrasive attack from the process gases, volatile metal compounds, and entrained materials. The un-normalized EDS results show that the slag components were rich in $\mathrm{FeO}$ (27 wt.\%), $\mathrm{SiO}_{2}$ (17 wt.\%) and $\mathrm{Al}_{2} \mathrm{O}_{3}$ (30 wt.\%), $\mathrm{Cr}_{2} \mathrm{O}_{3}$ (17 wt.\%), and $\mathrm{NiO}$ (8.3 wt.\%). The presence of these oxides on the surface of the bricks can be attributed to the entrainment and oxidation of metal and slag droplets ejected from the steel bath during arcing (Sofilić et al., 2004). In particular, the high contents of $\mathrm{Cr}_{2} \mathrm{O}_{3}$ and $\mathrm{NiO}$ observed can be attributed to the highalloy steel scrap and alloying elements commonly used in the production of special grades of steel.

It is clear that the severe thermal degradation could have increased the susceptibility of the brick to penetration by the process materials. The B2-interface also had uncharacteristically high amounts of copper and zinc oxides, which is indicative of the high level of contamination in the brick from the impurities present in the feed. Buzin et al. (2015) noted that electric arc

\section{Brick (b)-Electrode area}

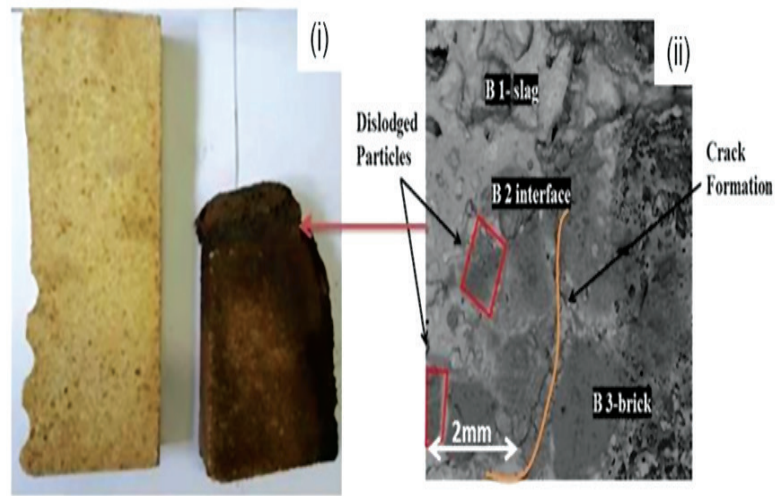

\begin{tabular}{|c|c|c|c|c|c|c|c|c|c|c|c|c|c|}
\hline \begin{tabular}{|l|} 
Composition \\
area
\end{tabular} & $\mathrm{Al}_{2} \mathrm{O}_{3}$ & $\mathrm{SiO}_{2}$ & $\mathrm{CaO}_{\mathrm{a}} \mathrm{O}$ & $\mathrm{Mg}_{9} \mathrm{O}$ & $\mathrm{FeO}$ & $\mathrm{MnO}$ & $\mathrm{TiO}_{2}$ & $\mathrm{NiO}$ & $\mathrm{Zn} 0$ & $\mathrm{~N}_{4}, 0$ & $\mathrm{~K}_{2} \mathrm{O}$ & $\mathrm{CuO}$ & \\
\hline B1-slag & 30 & 17 & 0 & 0 & 27 & 0 & 0 & 8.3 & 0 & 0 & 0 & 0 & 17 \\
\hline B2 - Interface & 45 & 14 & 3.7 & 1 & 14 & 0.5 & 2 & 0 & 8.1 & 5 & 2 & 0.51 & 0.3 \\
\hline -Brick & 63 & 24.5 & 0.5 & 0 & 1.6 & 0 & 2.5 & & 1.12 & 2.3 & 3 & 0 & \\
\hline
\end{tabular}

Figure 6-Characterization of brick (b) showing (i) the pictorial representation of the brick, (ii) the backscattered electron image, and (iii) un-normalized EDS compositional (mass\%) analysis

furnace dust may contain varying levels of compounds of metals such as $\mathrm{Pb}, \mathrm{Cd}, \mathrm{Ni}$, and $\mathrm{Cu}$, which can contribute to the corrosion of the bricks.

\section{Characterization of brick (c)}

Figure 7 shows the brick excavated from the off-gas chute area. Compared to brick (a), the SEM image of brick (c) also exhibited signs of crack formation (orange line) potentially resulting from the intermittent thermal stresses from the high temperature conditions experienced in the electrode area.

Based on the preliminary observations highlighted in Figures 5-7, brick (a) was considered suitable for reclamation. Brick (b) was rejected on the grounds of having experienced severe thermal degradation and contamination by process materials. Although brick (c) showed fewer tendencies of degradation,

Brick (c)- Off-gas chute

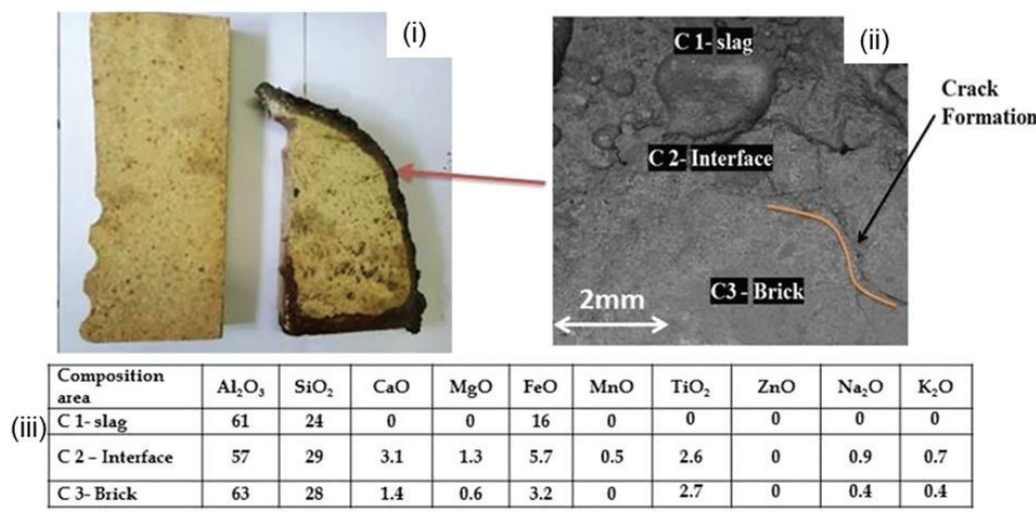

Figure 7-Characterization of brick (c) showing (i) the pictorial representation of the brick, (ii) the backscattered electron image, and (iii) un-normalized EDS compositional (mass $\%)$ analysis 


\section{Effect of reclaimed bauxite on andalusite-based refractory castables for tundish applications}

it was rejected on the grounds of economic viability due to potentially low quantities of the reclaimable portions at the end of each campaign. After rejecting bricks (b) and (c) for recycling, further confirmatory tests were conducted on brick (a) and the findings were compared to the virgin bauxite brick in order to further determine the suitability of the brick for reclamation. The XRD analyses also confirmed insignificant differences in the mineralogical phases between the virgin and reclaimed bricks, as indicated in Table III. Based on these considerations, brick (a) was considered suitable for reclamation. Further formulation tests were then conducted on this sample.

The findings in Tables II and III can be correlated to refractory phases for the bauxite bricks (> $\left.80 \% \mathrm{Al}_{2} \mathrm{O}_{3}\right)$. According to Brosnan (2004), corundum and mullite are the main refractory phases present in fired $\left(1450-1550^{\circ} \mathrm{C}\right)$ bauxite materials. The amorphous phases shown in Table III are usually associated with the presence of glassy silica and other indigenous impurities (e.g. $\mathrm{Na}_{2} \mathrm{O}, \mathrm{K}_{2} \mathrm{O}, \mathrm{Fe}_{2} \mathrm{O}_{3}, \mathrm{FeO}$, and $\mathrm{TiO}_{2}$ ) (Brosnan, 2004). However, the high content of these phases in the two samples is of substantial concern as they affect the solidus temperatures of bauxite refractories

\section{Characterization of formulated castables}

As discussed earlier, the alumina-based castables were formulated based on the varying the ratio of reclaimed bauxite to virgin andalusite. Table IV shows the oxide composition of the formulated castables as measured by XRF.

It is clear that the $\mathrm{Al}_{2} \mathrm{O}_{3}$ content of the castable increases with an increase in the amount of reclaimed bauxite in the castable. This is due to the fact that the reclaimed bauxite inherently contains a higher proportion of alumina compared to virgin andalusite (VS) (Harbison and Walker, 2000). Given the higher $\mathrm{Al}_{2} \mathrm{O}_{3}$ content of the formulated castable, the performance of the refractory castables can thus be assumed to approach that of bauxite. The $\mathrm{CaO}$ content of 1.5-1.8 wt.\% for the formulated castable is also congruent with the $\mathrm{CaO}$ tolerance for low-cement castables (LCCs) as classified by other researchers (Parr et al., 1997; Lee et al., 2001; Garbers-Craig, 2008). The slight increase

\section{Table III}

\section{Comparative quantitative XRD analyses of reclaimed} and virgin bauxite bricks (\%)

\begin{tabular}{l|c|c|} 
Phases present & Reclaimed brick A & Virgin bauxite brick \\
\hline Corundum & 35.79 & 38.68 \\
Mullite & 41.36 & 32.69 \\
Magnesia & 0.2 & 0.25 \\
Quartz & 0.57 & 0.04 \\
Iron & 0.07 & 0.11 \\
Amorphous & 22.01 & 27.88 \\
\hline
\end{tabular}

\section{Table IV}

Oxide composition of formulated castables (\%)

\begin{tabular}{|l|l|l|l|l|l|}
\hline Oxide & VS & S1 & S2 & S3 & S4 \\
\hline $\mathrm{Al}_{2} \mathrm{O}_{3}$ & 61 & 63 & 65 & 69 & 70 \\
$\mathrm{SiO}_{2}$ & 37 & 34 & 32 & 28 & 27 \\
$\mathrm{CaO}$ & 1.6 & 1.5 & 1.7 & 1.6 & 1.8 \\
$\mathrm{MgO}$ & 0.1 & 0.0 & 0.0 & 0.0 & 0.0 \\
$\mathrm{Fe}_{2} \mathrm{O}_{3}$ & 0.7 & 0.9 & 1.0 & 1.1 & 1.2 \\
\hline
\end{tabular}

in $\mathrm{Fe}_{2} \mathrm{O}_{3}$ can be attributed to the bauxite grog aggregate, which inherently picks up $\mathrm{Fe}_{2} \mathrm{O}_{3}$ as an impurity from process materials (Hancock, 2000; Pivinskii, Dyakin, and Perepelitsyn, 2015). Regrettably, the presence of impurities such as $\mathrm{Fe}_{2} \mathrm{O}_{3}$ tends to significantly affect the high-temperature strength properties of the formulated refractory castables.

\section{Water addition and flow behaviour of formulated castables}

Table V highlights the flow behaviour of the formulated castable. The installation method for the tundish permanent lining requires that the flowability of the castable be acceptable immediately after mixing. Thus, the thixotropic, workability and predictable placement properties are particularly important for both vibratable and non-vibratable castables (Pivinskii, 1998; Schnabel, Buhr, and Dutton, 2012). In practice, a castable with good flow properties at a low water mixing ratio tends to form a homogenous and well consolidated product (Zawrah and Khalil, 2001). From Table V, it is evident that the flow properties of the grog-containing castables deteriorated with increasing addition of grog. The observed trend can be correlated to the increased water requirements of the higher grog formulations. Technically, the higher the amount of grog, the higher the amount of water required to maintain the same level of flow and workability properties (Hanagiri et al., 2008). In practice, poor flow and placing properties in castables are often solved by increased water additions, albeit at the expense of other critical parameters such as open porosity, bulk density, and strength (Hanagiri $e t$ al., 2008; Schnabel, Buhr, and Dutton, 2012). Zawrah and Khalil (2001) proposed that excess water can reduce the strength and increase the shrinkage of the castable, while too little water can result in voids and poor consolidation.

\section{Apparent porosity and bulk density}

Table VI shows the results of open porosity and bulk density tests conducted at different temperatures. As expected, the apparent porosity increased gradually with an increase in the amount of grog. Frulli (2016) stated that the increase in apparent porosity can be attributed to the increased amount of bauxite

\begin{tabular}{|c|c|c|c|c|c|}
\hline \multicolumn{6}{|c|}{$\begin{array}{l}\text { Water addition and flow behaviour of formulated } \\
\text { products }\end{array}$} \\
\hline Physical property & VS & S1 & S2 & S3 & S4 \\
\hline $\begin{array}{l}\text { Water addition (\%) } \\
\% \text { Flow behaviour (after } 30 \text { seconds) }\end{array}$ & $\begin{array}{c}6 \\
165\end{array}$ & $\begin{array}{c}7 \\
150\end{array}$ & $\begin{array}{c}7 \\
155\end{array}$ & $\begin{array}{l}7.5 \\
145\end{array}$ & $\begin{array}{c}8 \\
140\end{array}$ \\
\hline
\end{tabular}

Table VI

Open porosity and bulk density of formulated products

\begin{tabular}{|l|c|c|c|c|c|l|}
\hline \multicolumn{2}{|l|}{ Property } & VS & S1 & S2 & S3 & S4 \\
\hline Open porosity $(\%)$ & $110^{\circ} \mathrm{C}$ & 2.3 & 2.8 & 2.5 & 2.7 & 4.0 \\
& $600^{\circ} \mathrm{C}$ & 4.1 & 4.8 & 4.8 & 4.9 & 4.8 \\
& $1000 \circ \mathrm{C}$ & 5.1 & 5.2 & 5.2 & 5.2 & 5.5 \\
& $1200^{\circ} \mathrm{C}$ & 5.0 & 5.1 & 5.3 & 5.5 & 5.5 \\
\hline Bulk density $\left(\mathrm{kg} / \mathrm{m}^{3}\right)$ & $110^{\circ} \mathrm{C}$ & 2.54 & 2.54 & 2.52 & 2.46 & 2.47 \\
& $600^{\circ} \mathrm{C}$ & 2.52 & 2.48 & 2.49 & 2.48 & 2.48 \\
& $1000^{\circ} \mathrm{C}$ & 2.50 & 2.49 & 2.48 & 2.45 & 2.47 \\
& $1200^{\circ} \mathrm{C}$ & 2.58 & 2.52 & 2.49 & 2.43 & 2.48 \\
\hline
\end{tabular}




\section{Effect of reclaimed bauxite on andalusite-based refractory castables for tundish applications}

grog addition in the castable, since the refractory materials based on bauxite or chamotte exhibit higher porosity than andalusitebased materials. The effect of the amount of grog is clearly observed in samples S3 and S4 fired at $1000^{\circ} \mathrm{C}$ and $1200^{\circ} \mathrm{C}$. Since these castables had higher water requirements (see Table IV) than the reference castable, the higher porosity can be attributed to disappearance of water of crystallization and hydration, which created porosity in the castable body structure without any meaningful bonding taking place (Kumar et al., 2014). At fixed firing temperature of $1000^{\circ} \mathrm{C}$, it can be inferred that the pore volume remained almost unchanged from VS to S3, but increased in S4 due to the apparent effect of grog addition (Zawrah and Khalil, 2001). Nevertheless, since low-cement castables (LCCS) usually possess open or apparent porosity values not higher than 10\% (Lee et al., 2001), the values obtained for the formulated castables were considered acceptable for the proposed applications.

Despite the marginal changes at intermediate firing temperatures of $600^{\circ} \mathrm{C}$ and $1000^{\circ} \mathrm{C}$, it is clear that the bulk density decreased with increasing grog addition, particularly at $110^{\circ} \mathrm{C}$ and $1200^{\circ} \mathrm{C}$. The observed trend is contrary to what was expected, since the higher order formulations contained more alumina, which is generally denser. Nonetheless, the observations from the present study are congruent with those of previous studies. Hutton et al. (2009) proposed that reclaimed refractory materials tend to have lower bulk density and higher porosity values compared to virgin materials.

The bulk density is indicative of good particle size packing and porosity, and would thus correlate to the wear resistance of the refractory castables (Harbison and Walker, 2005). The apparent or open porosity, on the other hand, is a measure of the effective open pore space in a castable. Apparent porosity is thus indicative of the bulk density and wear resistance, i.e., the higher the bulk density and the lower the apparent porosity, the higher the resistance to chemical attack, slag-metal penetration, and abrasion resistance. Higher bulk density values are desirable in refractory castables, as such properties significantly affect the performance. Lee et al. (2001) proposed that the higher the bulk density, the higher the hot strength, and hence the higher the abrasion and corrosion resistance under service conditions. As such, the observed decrease in the bulk density with an increase in the amount of grog is likely to affect such high-temperature properties of the castable. As a result, it is important to further optimize the amounts of grog, reactive calcined alumina, and microsilica addition to enhance the packing density, and the nature and amount of bonding phases in the formulated castables (Pivinskii, 1998; Zawrah and Khalil, 2001; Parr, Fryda, and Wöhrmeyer, 2013; Sadik, El-Amraniand, and Albizane, 2014; Tomba-Martinez et al., 2017).

\section{Static corrosion tests on formulated products}

Table VII shows the chemical composition of the slag used in the static corrosion tests. Due to the mismatch between the high

\section{Table VII}

\section{Normalized chemical composition of slag (wt.\%)}

\begin{tabular}{|l|c|c|c|c|}
\hline $\mathrm{CaO}$ & $\mathrm{SiO}_{2}$ & $\mathrm{FeO}$ & $\mathrm{MgO}$ & $\mathrm{Al}_{2} \mathrm{O}_{3}$ \\
\hline 32 & 31 & 14 & 16 & 7 \\
\hline
\end{tabular}

$\mathrm{Al}_{2} \mathrm{O}_{3}$ content of the castable formulations and the process slag, interaction between the slag and safety lining can be expected at higher temperatures should the working lining diminish to critical levels. Although the safety lining is not in direct contact with the slag unless the $\mathrm{MgO} \cdot \mathrm{SiO}_{2}$ working lining diminishes completely, the corrosion tests were nevertheless conducted as a precautionary measure.

Figure 8 shows the results of the static corrosion tests conducted at $1400^{\circ} \mathrm{C}$ for 12 hours. As was expected, a high corrodibility, evaluated based on the $\mathrm{Al}_{2} \mathrm{O}_{3}$ pick-up in the slag phase, of the castable by basic slag, was observed. For example, the $\mathrm{Al}_{2} \mathrm{O}_{3}$ content of the slag phase in VS, S1, S2, and S3 increased to around $27 \%$ compared to $7 \mathrm{wt} . \%$ in the original slag. However, the relative impact of $\mathrm{Al}_{2} \mathrm{O}_{3}$ content and physical properties such as bulk density and open porosity of formulated castables is not clear up to S3. S4, with 28 mass\% grog addition, higher open porosity, and lower bulk density, experienced higher slag attack as evidenced by the elevated pick-up of $\mathrm{Al}_{2} \mathrm{O}_{3}$ by the slag. Furthermore, it can be inferred that the slagcastable interaction occurred via the slag penetrating through the available pathways (open pores, cracks, phase boundaries, etc.), with the degree of penetration being controlled by the bulk density and apparent porosity of the castables (Pivinskii, 1998; Zawrah and Khalil, 2001; Poirier et al., 2008; Braulio et al., 2011; Sako, Braulio, and Pandolfelli, 2012; Parr, Fryda, and Wöhrmeyer, 2013; Kumar et al., 2014; Sadik, El-Amraniand, and Albizane, 2014; Tomba-Martinez et al., 2017). Thus, the corrosion behaviour indicates the need to further optimize the bulk density and open porosity properties of the formulated castables.

In principle, corrosion reactions should be viewed as attempts by the system to achieve compatibility by progressing towards equilibrium (Brosnan, 2004; Sako, Braulio, and Pandolfelli, 2012). Sako, Braulio, and Pandolfelli (2012) proposed that $\mathrm{Al}_{2} \mathrm{O}_{3}$ dissolution can be expected as a result of the interaction of $\mathrm{CaO}$-rich slags and $\mathrm{Al}_{2} \mathrm{O}_{3}$-rich refractory aggregate. Based on the approximate stoichiometric ratios of the $\mathrm{CaO}$ and $\mathrm{Al}_{2} \mathrm{O}_{3}$ of $2: 1$ observed for the slag phases, the reaction between the $\mathrm{Al}_{2} \mathrm{O}_{3}$ in the castables and the $\mathrm{CaO}$ in slag can be expected to occur via the formation of calcium dialuminate $\left(\mathrm{CaO} \cdot 2 \mathrm{Al}_{2} \mathrm{O}_{3}\right)$ intermediate phases. The formation of the $\mathrm{CaO} \cdot 2 \mathrm{Al}_{2} \mathrm{O}_{3}$ phases from the corrosion attack on alumina-based refractories by process slag is also supported by findings from other studies (Lee and Zheng, 2004; Melcher, Reiter, and Harmuth, 2007; Poirier et al., 2008). Lee and Zheng (2004) proposed that the dissolution of $\mathrm{Al}_{2} \mathrm{O}_{3}$ occurs indirectly with the formation of intermediate phases $\mathrm{CaO}$. $2 \mathrm{Al}_{2} \mathrm{O}_{3}$ and $\mathrm{CaO} \cdot 6 \mathrm{Al}_{2} \mathrm{O}_{3}$ under static conditions, with the direct dissolution of $\mathrm{Al}_{2} \mathrm{O}_{3}$ under dynamic and more aggressive slag conditions. Melcher, Reiter, and Harmuth (2007) also proposed that the corrosion mechanism of alumina spinel castables by steelmaking slags (basicity $0.80 \mathrm{CaO} / \mathrm{SiO}_{2}+\mathrm{Al}_{2} \mathrm{O}_{3}<1.54$ ) involves the formation of $\mathrm{CaO} \cdot 2 \mathrm{Al}_{2} \mathrm{O}_{3}$ and $\mathrm{CaO} \cdot 6 \mathrm{Al}_{2} \mathrm{O}_{3}$ phases from the concomitant diffusion of reacting species $\left(\mathrm{Al}_{2} \mathrm{O}_{3}\right.$ from the refractory surface and $\mathrm{CaO}$ from the slag) towards the slag/ refractory interface.

The change in the volume of corroded portions was used to further interpret the extent of corrosion of the $\mathrm{Al}_{2} \mathrm{O}_{3}$-castable by basic tundish slags. Based on the initial castable dimensions (50 $\mathrm{mm} \Phi$ and $35 \mathrm{~mm}$ depth), the corresponding volume change after reaction was calculated by measuring the changes in the diameter and depth as a result of slag penetration. Table VIII 


\section{Effect of reclaimed bauxite on andalusite-based refractory castables for tundish applications}

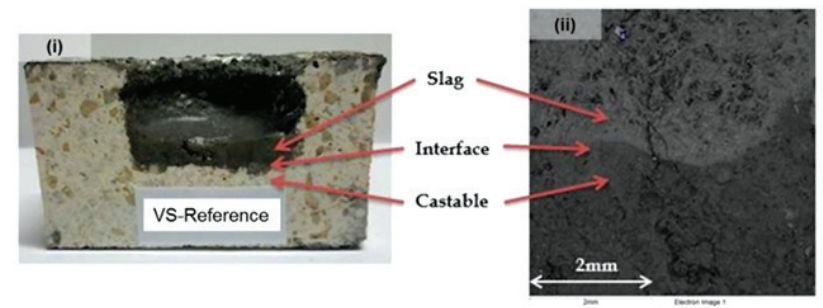

\begin{tabular}{|c|c|c|c|c|c|c|c|c|c|c|}
\hline vS $\mathrm{EDS}$ & $\mathrm{Al}_{2} \mathrm{O}_{3}$ & $\mathrm{SiO}_{2}$ & $\mathrm{CaO}$ & $\mathrm{MgO}$ & $\mathrm{FeO}$ & $\mathrm{MnO}$ & $\mathrm{TiO}_{2}$ & $\mathrm{SO}_{3}$ & $\mathrm{Na}_{2} \mathrm{O}$ & $\mathrm{K}_{2} \mathrm{O}$ \\
\hline Slag & 27 & 36 & 19 & 5 & 5 & 3 & 0.6 & 3 & 0.7 & 0.7 \\
\hline Interface & 45 & 36 & 9 & 3 & 3 & 1 & 0.3 & 0.7 & 0.5 & 0.4 \\
\hline Castable & 55 & 40 & 2 & 0 & 0.9 & 0 & 0.3 & 0.4 & 0.39 & 0.4 \\
\hline
\end{tabular}

(a) Reference formulation

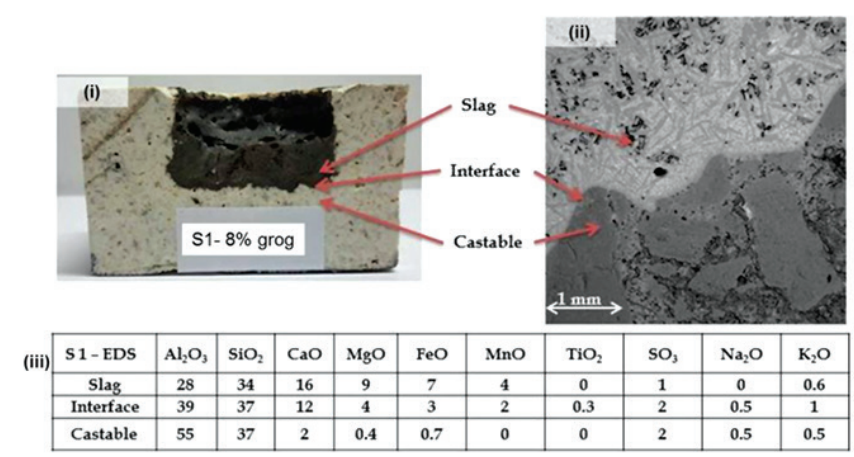

(b) S1 - 8 mass grog

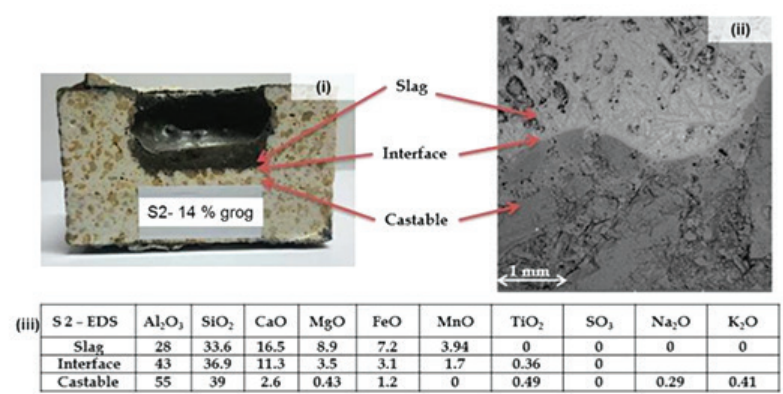

(c) $\mathrm{S} 2-14$ mass $\%$ grog

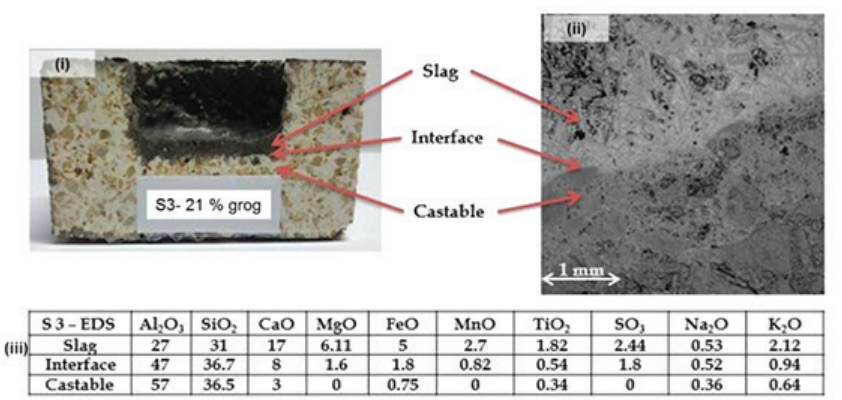

(d) $\mathrm{S} 3-22$ mass $\%$ grog

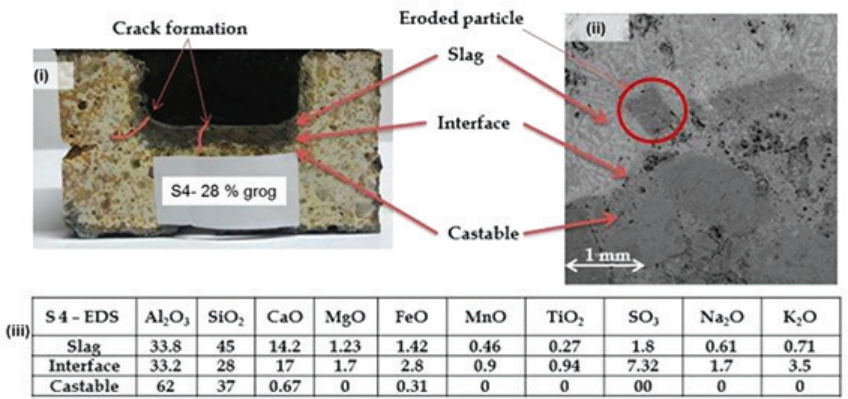

(c) $\mathrm{S} 4-28$ mass $\%$ grog

Figure 8-Results for static corrosion tests for the formulated castables showing (i) the pictorial representation of the sample, (ii) the backscattered electron image, and (iii) un-normalized EDS compositional (mass\%) analysis 


\section{Effect of reclaimed bauxite on andalusite-based refractory castables for tundish applications}

$\begin{aligned} & \text { Table VIII } \\
& \text { Corrosion volume (\%) of the formulated samples }\end{aligned}$
\begin{tabular}{|l|c|c|c|c|c|} 
Sample & $\begin{array}{c}\text { Initial volume } \\
\left(\mathbf{m m}^{3}\right)\end{array}$ & $\begin{array}{c}\text { Average) } \\
\mathbf{\Phi}(\mathbf{m m}\end{array}$ & $\begin{array}{c}\text { Average } \\
\text { depth }(\mathbf{m m})\end{array}$ & $\begin{array}{c}\text { Final } \\
\text { volume }\left(\mathbf{m m}^{3}\right)\end{array}$ & $\begin{array}{c}\% \mathbf{\Delta V} \\
\text { Corrosion }\end{array}$ \\
\hline VS & 68750 & 53.5 & 35.5 & 79836.33 & 16.13 \\
S1 & 68750 & 53.2 & 35.5 & 78943.48 & 14.83 \\
S2 & 68750 & 53.5 & 35.0 & 78711.88 & 14.49 \\
S3 & 68750 & 53.2 & 35.0 & 77831.60 & 13.21 \\
S4 & 68750 & 54.0 & 35.5 & 81335.57 & 18.31 \\
\hline
\end{tabular}

shows that lower corrosion volume changes (\%) were observed for S1, S2, and S3 compared against the reference VS. In essence, the relatively lower the percentage $\Delta \mathrm{V}_{\text {corrosion }}$, the higher the resistance to slag attack and the better the performance of the castable when exposed to slag conditions in the tundish (Parr, Wöhrmeyer, and Steffes-Tun, 2003). Likewise, S4, with 28 mass\% grog additions, a higher open porosity, and a lower bulk density, experienced higher $\% \Delta \mathrm{V}_{\text {corrosion }}$.

The better corrosion resistance of S1, S2, and S3 may be attributed to the substitution of andalusite aggregate by bauxite with a higher refractoriness (Harbison and Walker, 2000). Harbison and Walker (2000) proposed that the refractoriness of alumina-based refractories is a function of alumina content, due to the fact that the aggregate grog, which is $80 \%$ bauxite, is added to replace $<60 \%$ alumina virgin andalusite in the castable. However, the benefits of higher refractoriness of bauxite were negated in S4 due to negative synergistic effects of water addition, increased open porosity, and lower bulk density which, in essence, potentially increased the susceptibility to corrosion attack.

XRD analyses were conducted on the unreacted portions of the samples after the static corrosion tests (Table IX). Basically, the amounts of mullite and corundum phases increased with increasing amount of grog. This is due to the higher $\mathrm{Al}_{2} \mathrm{O}_{3}$ contents of the grog aggregates compared to the reference andalusite-based castable (Ødegård et al., 1998). Furthermore, the ratios of $\mathrm{Al}_{2} \mathrm{O}_{3}$ and $\mathrm{SiO}_{2}$ in the formulated castables are close to the stoichiometric ratio for the formation of the mullite $\left(3 \mathrm{Al}_{2} \mathrm{O}_{3}\right.$. $2 \mathrm{SiO}_{2}$ ) phases during firing and under service conditions. In essence, the formation of mullite can be represented to occur according to Equation [1] (Rebouillat and Rigaud, 2002; Hill and Sehnke, 2006; Garbers-Craig, 2008; Frulli, 2016).

The volume and distribution of the mullite and corundum phases is particularly critical to the performance of the formulated castables. Mullite, in particular, provides chemical stability to resist corrosion attack, and as such, the better corrosion resistance of S1, S2, and S3 can be attributed to the increased amounts of these phases in the castables (Zawrah and Khalil, 2001; Rebouillat and Rigaud, 2002; Garbers-Craig, 2008; Abou-Sekkina et al., 2011; Frulli, 2016; Tomba-Martinez et al., 2017). Although S4 was expected to have higher resistance to slag attack due to the greater amounts of mullite and corundum phases, the integrity of the formulation was negated by synergistic effects of poor physicochemical properties such as bulk density and open porosity (Kumar et al., 2014).

The effect of volume distribution of amorphous phases on the corrosion resistance of the castables is not clear from the findings. However, it can be inferred that the impurities in the raw materials (e.g., $\mathrm{Fe}_{2} \mathrm{O}_{3}, \mathrm{Na}_{2} \mathrm{O}, \mathrm{TiO}_{2}$, and $\mathrm{K}_{2} \mathrm{O}$ in andalusite VS, and $\mathrm{Fe}_{2} \mathrm{O}_{3}$ in recycled grog) could have reacted with the $\mathrm{Al}_{2} \mathrm{O}_{3}$ and $\mathrm{SiO}_{2}$ to form amorphous glass phases. Nevertheless, with the exception of S1 and S3, the amount of amorphous phases is congruent with the $10-15 \%$ proposed for high-alumina refractories (Yuan et al., 2015).

\section{Hot modulus of rupture (HMOR) at $1500^{\circ} \mathrm{C}$}

The thermomechanical properties of castables as a function of grog addition are presented in Figure 9. In general, castables with a higher recycled component demonstrated better HMOR properties at $1500^{\circ} \mathrm{C}$ compared to the reference specimen. For example, S1 and S3, with comparatively higher mullite contents (see Table VIII), achieved the highest HMOR values of $2.12 \mathrm{MPa}$ and $2.68 \mathrm{MPa}$, respectively. Congruent with findings from other studies, the formation of mullite significantly increases the hot strength properties of refractory castables (Myhre, 1994; Parr et al., 1997; Zawrah and Khalil, 2001; Rebouillat and Rigaud, 2002; Kumar, Kumar-Singh, and Strivastava, 2013; Kumar et al., 2014; Frulli, 2016). In fact, the higher HMORs for S1 and S3 can be attributed to both the higher mullite content and lower amount of amorphous phases, as indicated in Table VIII. Due to the ease of formation of liquid phases at high temperatures, amorphous glass phases have a significant effect on the thermomechanical properties of $\mathrm{Al}_{2} \mathrm{O}_{3}$-based refractories (Yuan et al., 2015). In addition, the values of HMOR of LCCs available in the literature are several orders higher than those obtained in this study (Chakraborty, 2004; Kumar et al., 2014), and the discrepancy is worth investigating in the future studies.

\section{Economic considerations}

As discussed earlier, the recycling of reclaimed bauxite refractory bricks results in significant cost savings by reducing reliance on virgin andalusite raw materials. The proposed recycling and re-use of these materials will result in reduced costs of landfill disposal, thereby reducing the overall cost of ownership of the

\section{Table IX \\ Phase analysis of unreacted portions of castables afterstatic corrosion test}

\begin{tabular}{|l|r|r|r|r|r|}
\hline Phases & VS & S1 & S2 & S3 & S4 \\
\hline Corundum & 2.7 & 7.6 & 11 & 13 & 18 \\
Mullite & 40 & 52 & 49 & 54 & 50 \\
Andalusite & 38 & 32 & 20 & 18 & 11 \\
Cristobalite & 0.15 & 0.44 & 0.06 & 0.11 & 0.02 \\
Anorthite & 3.7 & 4.7 & 4.2 & 4.8 & 4.7 \\
Amorphous & 15 & 3.1 & 16 & 9 & 12 \\
\hline
\end{tabular}

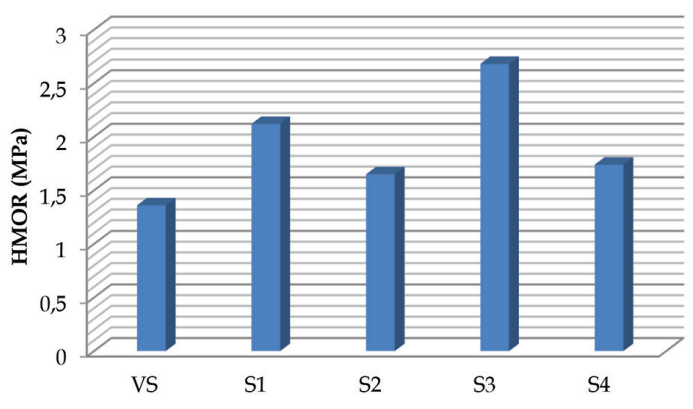

Figure 9-Comparative hot modulus of rupture values at $1500^{\circ} \mathrm{C}$ 


\section{Table X}

\section{Cost reduction from substitution of virgin andalusite per $\mathrm{kg}$ of formulated product}

\begin{tabular}{|c|c|c|c|c|c|c|c|c|c|c|c|}
\hline \multirow[t]{2}{*}{ Raw material } & \multirow[b]{2}{*}{ Unit costs } & \multicolumn{2}{|r|}{ VS } & \multicolumn{2}{|c|}{ S1 (8\% grog) } & \multicolumn{2}{|c|}{ S2 (14 \% grog) } & \multicolumn{2}{|c|}{ S3 (22\% grog) } & \multicolumn{2}{|c|}{ S4 (28\% grog) } \\
\hline & & kg & Total cost (\$) & kg & Total cost (\$) & kg & Total cost (\$) & kg & Total cost (\$) & kg & Total cost (\$) \\
\hline Binder premix & 19.22 & 75 & 1442 & 75 & 1442 & 75 & 1442 & 75 & 1442 & 75 & 1442 \\
\hline Calcined alumina & 21.56 & 20 & 431 & 20 & 431 & 20 & 431 & 20 & 431 & 20 & 431 \\
\hline Bauxite grog 0-1 mm & 3.43 & 0 & 0 & 20 & 69 & 40 & 137 & 60 & 206 & 80 & 274 \\
\hline Bauxite grog 1-3 mm & 3.43 & 0 & 0 & 35.5 & 122 & 71 & 244 & 107 & 367 & 142 & 487 \\
\hline Bauxite grog 3-6 mm & 3.43 & 0 & 0 & 15 & 51 & 30 & 103 & 45 & 154 & 60 & 206 \\
\hline Andalusite $200 \mu \mathrm{m}$ & 10.13 & 200 & 2026 & 200 & 2026 & 200 & 2026 & 200 & 2026 & 200 & 2026 \\
\hline Andalusite $0-1 \mathrm{~mm}$ & 8.53 & 200 & 1706 & 180 & 1535 & 160 & 1365 & 140 & 1194 & 120 & 1024 \\
\hline Andalusite $1-3 \mathrm{~mm}$ & 7.85 & 355 & 2787 & 319.5 & 2508 & 284 & 2229 & 248 & 1947 & 213 & 1672 \\
\hline Andalusite 3-6 mm & 10.6 & 150 & 1590 & 135 & 1431 & 120 & 1272 & 105 & 1113 & 90 & 954 \\
\hline Total cost (\$) & & & 10000 & & 9614 & & 9287 & & 9013 & & 8530 \\
\hline Total savings (\%) & & & 0 & & 4 & & 7 & & 10 & & 15 \\
\hline
\end{tabular}

refractories. In fact, it is proposed that at least $20 \%$ savings can be achieved by recycling alone (Bradley and Hutton, 2010). This section highlights the direct economic benefits from the formulations proposed in this study based on the replacement ratio of virgin andalusite. Table $\mathrm{X}$ illustrates the hypothetical costs of raw materials and the economic model for the cost reduction of substituting virgin raw material castable with reclaimed bauxite. The unit costs were assumed to include only the processing and sorting costs for the bauxite grog.

From the standard test results, it can be deduced that S1, S2, and S3 offered a better compromise between cost and quality of the formulated castable product. Increasing the replacement ratio from 8 mass $\%$ to 14 mass $\%$ grog increased the direct potential savings from $4 \%$ to $7 \%$. Potential savings of up to $15 \%$ can be achieved by further increasing the grog replacement ratio to 28 mass \%. Although S4 offers the highest cost reduction ratio, the results from the selected quality tests revealed that higher replacement ratios can compromise the quality of the refractory castables. In practice, higher cost reductions than those shown in Table X can be achieved if the costs of dumping space and other salient benefits such as goodwill for environmental stewardship were to be included in the cost calculations.

\section{Conclusion}

The study provides a pragmatic approach to the recycling of reclaimed bauxite bricks from the EAF roof. The effect of reclaimed bauxite on the performance of andalusitebased castables for tundish applications is discussed. The performance of formulated products was benchmarked to that of a refractory castable formulated from virgin andalusite. The diagnostic analyses of the bricks reclaimed from the periphery of the roof confirmed insignificant mineralogical differences to virgin andalusite bricks, and hence these bricks offered the best opportunities for recycling. The physical, thermal, and thermochemical behaviour of the products indicate that formulations S1 (8 mass\% grog), S2 (14 mass\% grog), and S3 (22 mass\% grog) offered the best compromise between the cost and quality of the castables. Neglecting indirect costs such as conveying and the cost of dumping space, the study demonstrated that direct potential savings of up to $10 \%$ can be achieved at a grog replacement ratio of 22 mass\% without compromising the product quality.

\section{Acknowledgements}

The authors acknowledge assistance from the University of Witwatersrand, Johannesburg and Scaw Metals Group.

\section{References}

Aвou-Seккina, M.M., Aвo-El-Enein, S.A., Khalil, N.M., and SAlma, O.A. 2011. Phase composition of bauxite-based refractory castables. Ceramics International, vol. 37. pp. 411-418

ASTM C1446. 2011. Standard test method for measuring consistency of self-flowing castable refractories. ASTM International, West Conshohocken, PA. https:// www.astm.org/Standards/C1446.htm [accessed 20 November 2017].

ASTM C583-15. 2015. Standard test method for modulus of rupture of refractory materials at elevated temperatures. ASTM International, West Conshohocken, PA. https://www.astm.org/Standards/C583.htm [accessed 20 November 2017].

ASTM C20-00. 2010. Standard test methods for apparent porosity, water absorption, apparent specific gravity, and bulk density of burned refractory brick and shapes by boiling water. ASTM International, West Conshohocken, PA. https:// edisciplinas.usp.br/pluginfile.php/2701821/ mod_resource/content/1/C20-00. pdf [accessed 1 January 2018].

Bradley, M. and Hutton, T. 2014. Recycling steel plant refractories. The Refractories Engineer, September. pp. 22-25.

Braulio, M.A.L., Tomba-Martinez, A.G., Luz, A.P., Liebske, C., and Pandolfelli, V.C. 2011. Basic slag attack of spinel-containing refractory castables. Ceramics International, vol. 37. pp. 1935-1945.

Brosnan, D.A. 2004. Corrosion of refractories. Refractories Handbook. Schacht, C.A. (ed.). CRC Press, Boca Raton, FL. pp 39-93.

Buhr, A., Koegel, O., and Dutton, J. 2013. Supply and demand of high alumina raw materials for refractories in Europe. Refractories World Forum, vol. 5, no. 3 . pp. 31-36.

ChaKRABoRTY, I.N. 2004. Comment on thermo-mechanical behaviuor of low cement castables derived from mullite aggregates synthesised from beach sand sillimanite. Ceramics International, vol. 30, no. 3. pp. 489-490.

DIN 51069 Blatt 2. 1972. Testing of ceramic material: Comparing test of the resistance of refractory bricks to the attack of solid and liquid materials at high temperature, crucible method. Prüfung keramischer Roh-und Werkstoffe, Vergleichende Prüfung des Verhaltens feuerfester Werkstoffe gegen den Angriff fester und flüssiger Stoffe bei hoher Temperatur. Tiegelverfahren (TV), Berlin.

De Buzin, P.J.W.K., Heck, N.C., and VileLA, A.C.F. 2017. EAF dust: An overview on the influences of physical, chemical and mineral features in its recycling and waste incorporation routes. Journal of Materials Research and Technology, vol. 6 , no. 2. pp. 194-202. 


\section{Effect of reclaimed bauxite on andalusite-based refractory castables for tundish applications}

FRuLl, D. 2016. Production and properties of refractory raw materials based on andalusite and mullite: Influence of impurities in the refractory behaviour. Refractories World Forum, vol. 8. pp. 1-4.

Fruhstorfer, J. and Aneziris, C.G. 2014. The influence of the coarse fraction on the porosity of refractory castables. Journal of Ceramic Science and Technology, vol. 5, no. 2. pp. 155-166.

Garbers-Craig, A.M. 2008. Presidential Address: How cool are refractory materials? Journal of the Southern African Institute of Mining and Metallurgy, vol. 108. pp. 491-506.

Guézennec, A.G., Huber, J.C., Patisson, F., Sessiece, P., Birat, J.P., and Ablitzer, D. 2005. Dust formation in electric arc furnace: Birth of particles. Powder Technology, vol. 157. pp. 2-11.

Hanagiri, S., Shimpo, A., Inuzuka, T., SaKaki, S., Matsul, T., Aso, S., Matsuda, T., and NaKagaWA, H. 2008. Recent improvement of recycling technology for refractories. Nippon Steel Technical Report no. 98. pp. 96-97.

Hancock, J.D. and Cannon, J.H. 2000. Practical Refractories. Refractories for Industrial Users. C\&H Group, Sasolburg, South Africa.

HARBISON AND WALKER. 2005. Handbook of Refractory Practice. Harbison-Walker Refractories, Moon Township, PA.

HILL, V.G. and SeHNKE, E.D. 2006. Bauxite. Industrial Minerals and Rocks: Commodities, Markets and Uses., 7th edn.. Kogel, J.E., Trivedi, N.C., and Barker, J.M. (eds.). Society for Mining, Metallurgy, and Exploration, Littleton, CO. pp. 227-262.

Hutton, T., Yates, V., Green, J., Coppack, J., and Goff, A. 2009. Reclaimed raw material resources and their use in modern monolithics refractories. The Refractories Engineer, September. pp. 20-25.

Kumar, P.H., SRivastava, A., Kumar, V., and Kumar-Singh, V. 2014. Implementation of industrial waste ferrochrome slag in conventional and low cement castables: Effect of calcined alumina. Journal of Asian Ceramic Societies, vol. 2. pp. 371-379.

Kumar, V., Kumar-Singh, V., and Strivastava, A. 2013. Low temperature synthesis of high alumina cements by novel co-melt precursors and their implementation as castables with some micro fine additives. Journal of the American Ceramic Society, vol. 96, no. 7. pp. 2124-2131.

Kumar, A., Khanna, R., Ikram-ul-HaQ, M., Spink, J., and Sahajwalla, V. 2015. Corrosion behaviour of $\mathrm{Al}_{2} \mathrm{O}_{3}-\mathrm{C}$ refractories with casting mould meniscus slags at 1 $550^{\circ} \mathrm{C}$. Steel Research International, vol. 87 , no. 1. pp. 46-56.

LeE, W. and Zhang, S. 2004. Direct and indirect slag corrosion of oxide and oxide-c refractories. Proceedings of the VII International Conference on Molten Slags, Fluxes and Salts. Southern African Institute of Mining and Metallurgy, Johannesburg. pp. 309-319.

Lee, W., Vieira, W., Zhang, S., Ghanbari Ahari, K., Sarpoolaky, H., and Parr, C. 2001. Castable refractory concretes. International Material Reviews, vol. 46. pp. $145-159$.

Mazzanti, F., Brentari, A., Burresi, E., Coglitore, A., Labanti, M., Martelli, S. Mingazzini, C., Ricci, A., Sangiorgi, S., Scafe, M., and Villa, M. 2010. Exploitation of ceramic wastes by recycling in alumina-mullite refractories. Proceedings of the 12th International Ceramics Congress, Montecatini Terme, Italy, 6-11 June 2010. Trchna, Faenza, Italy, pp. 9-14.

Melcher, F., Reiter, V., and Harmuth, H. 2007. Investigation of corrosion of different alumina spinel castables by ladle slags. RHI AG, Steel Division, Vienna, Austria. pp. 230-233.

Myhre, B., Sandberg, B., and Hundere, A.M. 1998. Flow and flow decay of refractory castables. Proceedings of the 3rd India International Refractories Congress. Indian Ceramic Society. pp. 11-13.

MrнRe, B. 1994. Strength development of bauxite-based ultra-low cement castables. Bulletin of the American Ceramic Society, vol. 73, no. 5. pp. 68-73.

Ndlovu, S., Simate, G.S., and Matinde, E. 2017. Waste Production and Utilization in the Metal Extraction Industries. CRC Press, Boca Raton, FL. https://doi. org/10.1201/9781315153896

Nyoka, M., Brazier, D., Courtney, T., and Parry, R.A. 2013. Merits of using andalusite-based refractories compared to bauxite-based refractories. Journal of the Southern African Institute of Mining and Metallurgy, vol. 113, no. 8. pp. 647-650.

ØDEGÅrd, C., Myhre, B. Hundere, M., and SAndBerg, B. 1998. Mullite bonded castable with andalusite as aggregate. Proceedings of the International Colloquium on Refractories, Aachen, Germany, 29-30 September. Verlag Stahleisen, Düsseldorf. pp. 2-5.

Parr, C. Bier, T., Bunt, N., and Spreafico, E. 1997. Calcium aluminate cement (CAC) based castables for demanding applications. Proceedings of the 1st Monolithic Conference, Tehran, Iran. pp. 3-11.

PARR, C., WöhrmeYer, C., and StefFes-Tun, W. 2003. The use of calcium aluminate cements in monolithic refractories for steel applications. Proceedings of the Prague International Conference on Refractories. pp. 2-13. https://docplayer. net/91410617-Technical-paper-the-use-of-calcium-aluminate-cements-inmonolithic-refractories-for-steel-applications-by-c-parr-c-wohrmeyer-w.html

PARR, C., Fryda, H., and WöHRMEYER, CH. 2013. Recent advances in refractories -aluminate binders and calcium aluminate bonded high-performance monolithic castables. Journal of the Southern African Institute of Mining and Metallurgy, vol. 113, no. 8. pp. 619-629.

PIVINSKII, Y.E. 1998. New refractory concretes and binding systems: Basic trends of development, production, and use of refractories in the 21st century. Part IC. Low-cement concretes and cement-free unshaped refractories. Refractories and Industrial Ceramics, vol. 39, no. 5-6. pp. 151-159.

Pivinski, Y.E., Dyakin, P.V., and PerepeltTsyn, V.A. 2015. Research in the field of preparing moulded and unmoulded refractories based on high-alumina HCBS. Part 1. High- alumina bauxite as a basic raw material component. Refractories and Industrial Ceramics, vol. 56, no. 4. pp. 344-350.

Poirier, J., QAfssaoui, F., Ildefonse, J.P., and Bouchetou, M.L. 2008. Analysis and interpretation of refractory microstructures in studies of corrosion mechanisms by liquid oxides. Journal of the European Ceramic Society, vol. 28. pp. 1557-1568.

Prigent, P., Bouchetou, M.L., and Poirier, J. 2011. Andalusite: An amazing refractory raw material with excellent corrosion resistance to sodium vapours. Ceramics International, vol. 37. pp. 2287--2296.

Rebouillat, L. and Rigaud, M. 2002. Andalusite-based high alumina castable. Journal of the American Ceramic Society, vol. 85, no. 2. pp. 373-378.

Sadik, C., El-Amrani, I.E., and AlbizAne, A. 2014. Recent advances in silica-alumina refractory: A review. Journal of Asian Ceramic Societies, vol. 2, no. 2. pp. 83-96.

Sako, E.Y. Braulio, M.A.L., and Pandolfelli, V.C. 2012. The corrosion and microstructure relationships for cement-bonded spinel refractory castables. Ceramics International, vol. 38. pp. 2177-2185.

Schutre, M. 2010. Refractory recycling - earning your environmental brownie points. Proceedings of the Refractories 2010 Conference. Misty Hills, Muldersdrif, 16-17 March 2010. Southern African Institute of Mining and Metallurgy, Johannesburg. pp. 75-82.

Schnabel, M., Buhr, A., Kockegey-Lorenz, R., Schmidtmeier, D., and Dutton, J. 2014 Benefits of matrix alumina and modern dispersing systems in low cement castables. Inteceram, vol. 63, no. 6. pp. 281-285.

Schnabel, M., Buhur, A., And Dutton, J. 2012. Rheology of high performance alumina and spinel castables. Refractories World Forum, vol. 4. pp. 95-100.

Sofilić, T., Rastovčan-Mıč, A., Cerjan-Stefanović, Š., Novosel-Radovič, V., and Jenko, M. 2004. Characterisation of steel mill electric-arc furnace dust. Journal of Hazardous Materials B109. pp. 59-70.

Tomba-Martinez, A.G., Luz, A.P., Braulio, M.A.L., Sako, E.Y., and Pandolfelli, V.C. 2017. Revisiting the CA6 formation in cement-bonded alumina-spinel refractory castables. Journal of the European Ceramic Society, vol. 37. pp. 5023-5034.

Yuan, W., Zhu, Q., Deng, C., and Zhu, H. 2015. The effect of glass phase on the modulus of rupture of high alumina refractories. Journal of Ceramic Science and Technology, vol. 6, no. 3. pp. 215-220.

ZaWRAH, M.F.M. and KHALIL, N.M. 2001. Effect of mullite formation on properties of refractory castables. Ceramics International, vol. 27. pp. 689-694. 